\title{
HISTORIA, ÉPICA Y NOVELA: MODELOS GENÉRICOS Y POÉTICA HISTÓRICA (EN EL SIGLO XVII)
}

\author{
Pedro Ruiz Pérez
}

\begin{abstract}
In Don Quijote Cervantes presents a crossroad where the process of reformulation of the canon of the poema épico (between Ariosto and Tasso), the development of the idealistic narrative and the ambivalent notion of history make problematic their relations. This is a symptom of a historic and aesthetic crisis that could be named barroco and that is a readjustement in the classicism sytem. Both parameters, the historic and the aesthetic, are conjugated to analyse the changes in the generic framework, specifically in the relations among hystory, epic and novel along the XVIIth century.
\end{abstract}

En pleno proceso creativo y editorial, Trillo y Figueroa da a la imprenta en $1651 \mathrm{La}$ Neapolisea. Poema heroico y panegírico, composición épica en 446 octavas y ocho cantos con la que culmina la definición teórica y práctica de una específica poética culta, la del panegírico, pues, "ajustado un panegírico a los términos de poema heroico, será la obra más grande que se puede proponer a la poesía" ". Sin embargo, no debió durar mucho la satisfacción por la fórmula alcanzada, pues de inmediato comienza el poeta la reelaboración de su obra, según declara en el prólogo de un nuevo texto, que fecha en 1672 y que constituye ya no sólo una obra diferente, sino un nuevo modelo genérico para la epopeya en verso ${ }^{2}$, como refleja la propia estructura externa (10 cantos con 1445 octavas) y la consiguiente modificación en la economía interna del poema y las relaciones entre las partes y el conjunto. La reescritura supone también un significativo desplazamiento en el modelo estilístico y retórico, que, junto con lo referente al equilibrio entre la fábula y los episodios, conforma un proceso de reconducción del modelo del poema épico hacia los planteamientos de restauración clasicista sostenidos por Torquato Tasso.

Con sus Discorsi y con las sucesivas redacciones de la Gerusalemme Liberata Tasso interviene en el debate iniciado por el Orlando Furioso de Ariosto y la dialéctica entre el

\footnotetext{
1 “Al que leyere", prólogo de La Neapolisea, subtitulado "Razón desta obra, partes de que se compone, estilo, imitación, intento y erudición”. Cito por F. de Trillo y Figueroa, Obras, ed. A. Gallego Morell (Madrid 1951) 421. Analizo sus planteamientos en "El poema panegírico de Trillo y Figueroa. Teoría y práctica de una poética postgongorina", Hommáge à Robert Jammes (Toulouse 1994) III, 1037-1049. Para el conjunto de su obra, véase P. Ruiz Pérez, "El sistema de los géneros poéticos en Francisco de Trillo y Figueroa”, Glosa, 2 (1991) 289-306.

${ }^{2}$ Para una noticia del texto, véase P. Ruiz Pérez, "El Poema heroico del Gran Capitán de Trillo y Figueroa. Un texto inédito para la historia de la épica y la poética culta del siglo XVII”, Angélica, 5 (1993) 105-112.
} 
romanzo y los modelos más clasicistas del poema épico, lo que vendría a representar en el plano de la poética más culta un correlato del debate generado en torno a los libros de caballerías y su lugar en una narrativa en prosa que sólo se acepta en la teoría poética vigente en sus imitaciones del modelo de Heliodoro. Entre ambos planos, el de la remodelación y adaptación de la épica y el del desarrollo y evolución de las formas narrativas idealistas, se sitúa a partir del Quijote el proceso de conformación de la moderna fórmula novelesca, en una cuestión de relaciones genéricas que se entrecruza de manera inseparable con un proceso de crisis histórica y estética, representado por el barroco o, de manera más amplia, por el reajuste del sistema clasicista. Desde el Quijote de 1605 al último poema de Trillo el fenómeno se desarrolla a lo largo del XVII en toda su complejidad, en una interrelación de ideas poéticas, modelos genéricos y cambio histórico, que no pueden contemplarse aisladamente, sino en esta misma dialéctica.

\section{La maleta de un ventero y un manuscrito inédito.}

En su venta (Quijote, I,32) Juan Palomeque el Zurdo discute a causa de los títulos que constituyen su arsenal de conocimientos librescos -que no lecturas- y entre los que se encuentra, emparedada entre Don Felixmarte de Hircania y Don Cirongilio de Tracia, la Historia del Gran Capitán Gonzalo Hernández de Córdoba, con la Vida de Diego García de Paredes. Bien es cierto que el cura discrimina entre ellos, oponiendo la "historia verdadera" a los "libros mentirosos" y "llenos de disparates y devaneos"; igualmente cierto es que las preferencias del paradigmático ventero son de similar rotundidad, al inclinarse por los romances caballerescos. No obstante, la percepción común es la de unos lazos de unión, cuando no de una apreciable familiaridad, entre estos relatos. Era la misma que debía tener -si no es que buscaba provocarla o exacerbarla- el responsable de la edición alcalaína de 1584 de la Crónica del Gran Capitán, a la que podría corresponder el ejemplar que obraba en la maletilla de Juan Palomeque. En la portada de dicha edición aparece como ilustración un grabado en que un caballero empenachado y con armadura completa blande sobre su cabeza un mandoble a lomos de un caballo rampante. Además de que este tipo de armamento resultaba ya en la época del Gran Capitán tan anacrónico como debiera resultarle a un lector de finales del XVI o como debieron percibir sus acompañantes las armas del caballero de la Triste Figura, la actitud resultaba totalmente impropia de un general de un ejército moderno como era Gonzalo Fernández, y sólo era acorde con la típica representación del caballero en su hipóstasis andante, tal como era formalizada por los libros que ocuparon la biblioteca y la cabeza de Alonso Quijano ${ }^{3}$.

\footnotetext{
${ }^{3}$ Sustituyendo los penachos por la filacteria con su nombre, la imagen del militar -armas, actitud, gesto, disposición, etc.- reproduce la del grabado que exorna la princeps del Amadís, pero también la de la portada de Don Cirongilio (1545), cuya cabeza, con gorro y barba, corresponde, sin embargo, a la iconografía del general renacentista. Del lado de la crónica, las ediciones del Quinientos de los textos medievales muestran el mismo modelo de representación y similares variantes, según se aprecia en la impresión de 1543 de la muy reeditada Crónica de Juan II (con armadura completa) y la de 1551 de la Crónica de Alfonso Onceno, que reproduce el grabado de Don Cirongilio. Véase ahora Edward Baker, La biblioteca de Don Quijote (Madrid 1997). Habría que acudir al Bernardo de Balbuena para mostrar un caso paralelo de mitificación caballeresca y novelización fabulosa del héroe, también con una base cronística, si no histórica; el apelativo de "doncel del mar" que el héroe de Roncesvalles recibe (libro IV) es ilustrativo, más allá de su conexión con Amadís, de esta contaminatio.
} 
Incluso cuando el cura sale en defensa de la crónica frente a los romances caballerescos, su argumentación vuelve a empujar la primera hacia el territorio de los segundos, en este caso centrándose en la figura de Diego de Paredes, cuya hazaña supera a la de Suero de Quiñones en el "paso honroso" registrado por Rodríguez de Lena, e incluso a las de los héroes de Feliciano de Silva: "Diego García de Paredes fue un principal caballero, natural de la ciudad de Trujillo, en Extremadura, valentísimo soldado, y de tantas fuerzas naturales, que detenía con un dedo una rueda de molino en la mitad de su furia; y puesto con un montante en la entrada de un puente, detuvo a todo un innumerable ejército que no pasase por ella, y hizo otras tales cosas, que si como él las cuenta y las escribe él asimismo con la modestia de caballero y de coronista propio, las escribiera otro, libre y desapasionado, pusieran en olvido las de los Hétores, Aquiles y Roldanes”. Parafraseando a Ginés de Pasamonte, “imal año para Amadís!”.

Cervantes presenta en esta síntesis narrativa la confluencia de las tres modalidades de "historia" que distingue el siglo XVI, tal como las formulara Rodríguez de Montalvo en el prólogo al Amadís ${ }^{4}$. De una parte, la propia obra de Don Quijote, en el camino de la novela, representa un ejemplo perfecto de la "historia de afición", en la que lo verosímil sustituye a lo real. A un extremo de ésta se encontraba la crónica, muestra de "historia verdadera", relación de hechos ocurridos en realidad; al otro extremo se situaban las derivaciones últimas de los romances caballerescos, en cuyas páginas se incluían sucesos que no sólo no habían sucedido, sino que eran imposibles, e increíbles de añadidura. Así pues, en los albores del siglo XVII Diego García de Paredes y el Gran Capitán competían en el gusto lector con la épica clásica, pero también con la materia ariostesca y de los propios romances caballerescos. Sin duda, esta recepción, que supone la existencia de un espacio común, formado por la intersección de historia, épica y novela, habría de mantenerse, con sus límites borrosos entre la verdad y la ficción y el espacio propicio para la verosimilitud, reclamada desde Aristóteles a Tasso, hasta mediados del XVII, cuando Trillo y Figueroa compone su Neapolisea y la ofrece al público, aunque quizá haya desaparecido dos décadas después, cuando el mismo autor no puede llevar a los lectores su nueva propuesta genérica sobre la misma materia argumental.

Los trasvases de características no faltan a lo largo de estos procesos, en los que la inclusión de sucesos fantásticos en historias verdaderas resuelve su verosimilitud por la mera apelación a la naturaleza cronística, como Cervantes recordara en el Quijote y planteara superar en el Persiles. En oposición simétrica, la materia del Gran Capitán se situaba en el lugar epistemológico y literario de la "historia verdadera", pero en su relación con la "historia de afición", y desde él se incorporaba a la constitución del poema épico, que en el canon seguido por Trillo se opone a la historia, pero se construye con material histórico; se sitúa en el ámbito aristotélico de la ficción imitativa, pero se alimenta de la propuesta tassesca y el modelo épico nacional de desarrollo argumental a partir de la historia ${ }^{5}$. Sin embargo, para la preceptiva de la

\footnotetext{
${ }^{4}$ Véase A.L. Fogelquist, "Amadís" y el género de la historia fingida (Madrid 1983). Nótese la relación de estas distinciones en la noción de "historia" con las diferencias que la retórica clásica establecía entre "fábula", "materia poética" y "materia histórica". Cfr. infra.

${ }^{5}$ Para la conformación de las relaciones entre ficción literaria y verdad en el canon horaciano, cfr. A. García Berrio, Formación de la teoría literaria moderna. La tópica horaciana en Europa (Madrid 1977) 163-188. Véase también A. Porqueras Mayo, "El problema de la verdad poética en el Siglo de Oro", Temas y formas de la literatura española (Madrid 1972) 94-113; y V. Frankl, El "Antijovio" de Gonzalo Jiménez de Quesada y las concepciones de realidad y verdad en la época de la Contrarreforma y el Manierismo (Madrid 1963).
} 
segunda mitad del XVII ya estaba meridianamente clara la distinción entre poesía e historia ${ }^{6}$, y, tras superar el sentimiento de inferioridad arrastrado por la primera desde la Edad Media hasta el Renacimiento ${ }^{7}$, conoce la orgullosa afirmación de la superioridad de la poesía, que, al pintar los hechos como debieron suceder y no sólo como sucedieron, alcanza lo universal sobre lo particular, equiparándose con la filosofía por encima de la historia ${ }^{8}$. La actitud encuentra campo abonado en el territorio de la épica, en el que la dicotomía entre el héroe y el poeta, entre los hechos y su canto, venía siendo resaltada desde la antigüedad clásica, en una progresiva afirmación del segundo elemento del par, hasta desembocar en la rotunda conciencia de que el poeta es quien crea al héroe a través de la fama que le proporciona con sus escritos ${ }^{9}$.

Aunque en el paso del disparatado romance a la novela cervantina opera un principio de rigor clásico, en torno al concepto de poema épico en prosa, que muestra cierta correspondencia con la dialéctica entre el romanzo ariostesco y la restauración propuesta por Tasso, la conformación de la poética narrativa del género novelesco conduce a formulaciones dispares, cuando no claramente opuestas, ya que la novela se aparta por igual de los modelos

\footnotetext{
${ }^{6}$ Caso distinto se da en la "proyección biográfica" que A. Prieto sitúa en el paradigma heredado del "canon de Ferrara" ["La poesía épica renacentista", en La poesía española del siglo XVI. II (Madrid 1987) 781-831], aunque la fusión mítica se produzca en espacios más amplios de la literatura del siglo XVI; $c f r$. A. Prieto, "De la materia histórica", Voz y Letra, I,2 (1990) 3-14.

7 Véase E.C. Riley, Teoría de la novela en Cervantes (Madrid 1989) 255 y ss.

${ }^{8}$ No fue ajena a este fenómeno la revalorización, tras la Poética, de la Retórica de Aristóteles a partir de su recuperación postrenacentista, con su atención a los aspectos de la inventio y su relación con la dialéctica filosófica. Cfr. G. Caravaggi, "Evoluzione di un presupposto aristotelico nell'epica ispanica del tardo Rinascimento (con uno studio su alcuni prologhi e proemi)", Cultura Neolatina, 23 (1963) 18-71.

${ }^{9} \mathrm{Cfr}$., a pesar de las diferencias existentes, el sentido que en esta línea aparece ya en el pétreo poema de Gómez de Figueroa Alcázar imperial de la fama del Gran Capitán (1513). Para el desarrollo de esta idea, encauzada en el motivo de las armas y las letras y encarnada en el personaje del Gran Capitán, véase, además de los datos recogidos por A. Soria, El Gran Capitán en la literatura (Granada, 1954), F. López Estrada, "Las armas y las letras: el Gran Capitán en el teatro de Lope de Vega”, Anales de la Universidad Hispalense, 15 (1954) 3-41. El ya mencionado prólogo del Amadís insiste en que en la confluencia de armas y letras, son éstas las que consagran a las armas en la fama, idea que también puede hallarse en el Arte de la poesía castellana de Juan del Encina, desde donde se extiende como un verdadero tópico por el espacio humanista del siglo XVI, alcanzando lugar destacado en la praefatio de Ginés de Sepúlveda a su Gonsalus, donde, recordando a Cicerón y Salustio, lamenta que las gestas militares españolas no hayan tenido el debido reflejo en las páginas de la literatura, que es la que les proporcionaría la gloria [cfr. A. Prieto, "El saber humanista", en P. Ruiz Pérez (ed.), Gramática y humanismo. Perspectivas del Renacimiento español (Madrid 1993) 87-108], idea que se desarrolla en el De honore de Fox Morcillo, impregnado ya plenamente del nacionalismo renacentista, de cuyo impulso "se impregnan el concepto de la historia como cauce de la fama y su contrastiva consideración en antiguos y modernos, al tiempo que la ausencia de una historia y una épica dignas irrumpe en el ámbito conceptual de la armonía deseable entre las armas y las letras", como señala J. Lara Garrido, "Confluencia de estructuras y sumarización de funciones en el diálogo renacentista (Un estudio sobre los Diálogos de la vida del soldado" de Núñez de Alba"), Analecta Malacitana, III,2 (1980) 186. Véase también R. Durling, The figure of the poet in Renaissance epic (Cambridge, Mass. 1965). Es conveniente recordar que tras su silencio editorial, además de la composición y corrección del Poema heroico del Gran Capitán, Trillo se dedicó casi en exclusiva a la historiografía, en sustitición de la poesía. El mismo año que data el manuscrito de su poema heroico, 1672, lo hace con el de su Apologético historial. Antigüedad y fundamento de la ciudad de Granada (ms. 321 del British Museum). Cinco años más tarde fechará el manuscrito de su Historia verídica general genealógica de España (Biblioteca del Seminario de San Carlos de Zaragoza), en el que es de notar su preocupación por destacar en el título las protestas de veracidad en esta labor.
} 
de la épica y de la historia ${ }^{10}$. Aunque inicialmente la novela debió compartir el público con la épica, la historia y el "romance" caballeresco, como ilustra el episodio quijotesco, su desarrollo debió ir exigiendo distintos niveles de decodificación, diferentes "horizontes de expectativas", pues sólo cuando el lector ingenuo, como el ventero cervantino, puede distinguir entre personas reales, héroes épicos y personajes de ficción novelesca, puede establecerse el desarrollo del nuevo género, en el que también tendrán una naturaleza novedosa las relaciones entre la fábula y los episodios, entre las partes y el conjunto, uno de los ejes determinantes de la caracterización clasicista, presente por igual en la autocrítica del Quijote de 1615, en las correcciones de la Gerusalemme Liberata y en la reelaboración del panegírico de Trillo en el Poema heroico del Gran Capitán.

\section{Poética barroca / poética(s) clasicista(s)}

La reaparición de un canon clasicista como fórmula de recuperación en la crisis del género épico, apreciable en España conforme avanzaba el siglo XVII, lo ubica también en el ocaso de la estética barroca. El hecho no deja de proponer llamativas relaciones entre la vigencia y desarrollo de los géneros, como discursos conformados por una tradición, y la actualidad de una poética, marcada por su historicidad. Se entrecruzan así las coordenadas de dos ejes que no siempre se encuentran en total sintonía: el del sistema genérico, con sus normas específicas, y el de la estética, cuya dialéctica de interinfluencias no opera en el plano de la abstracción, sino en el de la historia, que es el que determina la cambiante especificidad de estas relaciones, alteradas a lo largo del amplio decurso de vigencia de la poética del clasicismo.

Las fuerzas dispares que confluían en la poética clasicista se han presentado desde algunos comentarios de la Poética como parejas dicotómicas en oposición, identificadas con el arte y la naturaleza, Aristóteles y Platón, el Pinciano y Carvallo, los preceptos y la creatividad individual. La lectura peca de un excesivo y distorsionante simplismo, pero tiene la virtualidad de apuntar polos activos a lo largo del siglo XVI y no siempre en adecuada conciliación (cfr. García Berrio). Las tensiones generadas entre los elementos de estas polaridades alcanzaron en el paso del siglo XVI al XVII y en la primera década de éste una fuerza particular. Es decir, lo que en términos estéticos podría traducirse como la transición del manierismo al barroco. En esta crisis no sólo se forjó un nuevo período estético; también comenzaron a fijarse los nuevos modos genéricos y una relación distinta entre las reglas y la obra de arte. Mientras Lope encerraba bajo llave a Plauto y a Terencio para escribir su comedia, Góngora transgredía todos los límites impuestos para encauzar la poesía, y la ironía cervantina sacudía las bases de la narrativa, reclamando además para la prosa lo que venía siendo dominio casi exclusivo del verso: la épica. La poesía, desprovista en gran medida del asidero de las reglas, podía orientarse hacia más amplios horizontes, pero no sin un cierto sentimiento de inseguridad, producto de la crisis. El cambio se produce como una intersección entre una estructura histórica -la de una sincronía, nueva respecto a la pasada- y la "historia" de una estructura -la de un género o una forma-, que se manifiesta diacrónicamente en forma de tradición. Este cruce entre la historia y

10 Cfr. J. Blasco, "La compartida responsabilidad de la 'escritura desatada' del Quijote", Criticón ,46 (1989) 45. Véase también E. von Richthofen, Tradicionalismo épico-novelesco (Barcelona 1972). 
la memoria, que es propia de todo texto ${ }^{11}$, tiene un terreno privilegiado en el espacio del género y en cada una de sus actualizaciones, que son las que constituyen los textos concretos y, al tiempo, los cambios histórico-literarios ${ }^{12}$. Al margen de las grandes estructuras periodológicas, cuya conceptualización resulta inevitablemente una forma de abstracción, es en el ámbito concreto de cada uno de los géneros en el que se percibe de manera directa el cambio histórico y la crisis consiguiente, con la dialéctica entre el mantenimiento de la reglas y la innovación, de distinta naturaleza según se trate de géneros germinales o de los que cuentan con una arraigada y consagrada tradición.

La continuidad como una tradición de la herencia cultural, artística y aun estética grecolatina hasta la actualidad ya ha sido suficientemente puesta de relieve, como para que no resulte sorprendente la aparición de algunos de sus elementos en las épocas más dispares, incluyendo la medieval, la del romanticismo y la de las vanguardias. No es, por tanto, la pervivencia de estos factores aislados lo que determina la clasicidad de una época, sino la vigencia de una sistema estético completo, cerrado y coherente, a cuyos principios y reglas se somete toda creación, con independencia de los materiales y las formas que adopte para ello. No valen, por la misma razón, definiciones de raíz romántica y anticlásica, como la borgiana o la de Calvino, ni surgidas de la sanción otorgada por el paso del tiempo. No obstante, aunque el "ser todo para todos", o el ideal de equilibrio del que procede la perennidad de la obra, no son por sí mismas válidas, al menos desde el planteamiento histórico y poetológico que se demanda, sí tienen la virtualidad de apuntar uno de los pilares básicos de la estética clasicista: el que proclama la existencia y funcionalidad de los modelos, cuya repetición garantiza la perfección de la obra artística. La existencia de modelos se basa en la creencia en la perennidad de ciertas formas y garantiza la pervivencia de los mismos, al convertir una realización concreta en principio de una clase, en principio clasificador, en clasicidad. La vigencia de la clasis es la que sustenta el principio de auctoritas, de donde se desprende la existencia y el valor de las normas, que rigen la creación sometiéndola a arte, reducido a veces a una técnica basada en un conjunto de preceptos.

En este proceso se produce históricamente un sesgo del principio aristotélico de la mímesis, reducida a un estrecho y mecanicista concepto de imitatio, que conduce en muchos casos a la mera reiteración de lo expuesto por los auctores ${ }^{13}$, cuando no se trata de un franco saqueo o un simple centón. Desde esta perspectiva, podríamos hablar de la vigencia de la poética clasicista en tanto se mantiene este principio de la imitación y no es sustituido por un concepto moderno de la originalidad. Naturalmente, a ello no es ajeno un conjunto de transformaciones que se producen en la teoría poética alrededor del paso del siglo XVI al XVII, aunque en su asentamiento definitivo (mucho más lento) tendrán un papel decisivo la constitución de

\footnotetext{
${ }^{11}$ Véase Francisco Rico, "La tradición y el poema", en Breve biblioteca de autores españoles (Barcelona 1990) 269-300, donde actualiza nociones planteadas en trabajos anteriores. De manera más sistemática, Claudio Guillén, Literature as system (Princeton 1971), con trabajos más accesibles en Teorías de la historia literaria (Madrid 1989).

${ }^{12}$ Como señala Alberto Blecua, esto "es lo que persigue, o debe perseguir, el historiador de la literatura": "La literatura, signo histórico literario ¿Signos viejos o signos nuevos? Fino amor y religio amoris en Gregorio Silvestre", en La literatura como signo, coord. J. Romera Castillo (Madrid 1981) 111.

${ }^{13}$ Tal planteamiento se percibe en un comentarista tan representativo como el Brocense; véase P. Ruiz Pérez, "Las Anotaciones del Brocense. Retórica e ideas poéticas renacentistas", Rilce, IV,2 (1988) 73-98.
} 
géneros nuevos y las dificultades para someterlos a modelos clásicos, ya que éstos son inexistentes, como ocurrirá con la novela, en franca oposición a la poesía épica, pero también con la tragicomedia lopesca o la silva gongorina ${ }^{14}$. El Broncese marca la culminación de la vigencia del principio de la imitatio, característica de la época renacentista, dominada por un sentido humanista de la retórica, que propiciaba la existencia de una voz común, en la que los modelos y la auctoritas garantizaban la existencia de una clasis sobre las formas de expresión individualizadas. Entre las Anotaciones a Garcilaso de este autor (1574) y las de Herrera (1580) podría situarse la crisis manierista. Si la nueva etapa conoce un desplazamiento desde la retórica humanista a la poética neoaristotélica, supone también una inicial afirmación del principio de individualidad, resolviendo la tensión dialéctica entre la fuerza de la norma -con base en la imitatio- y el impulso del ingenio personal mediante el concepto de emulatio, que implicaba una nueva modalidad de relación con los modelos clásicos; consiguientemente, también una nueva forma de clasicismo o una evolución en él. El afianzamiento progresivo del segundo elemento de la dicotomía y su impulso a la aparición de nuevas formas, carentes de modelos y aún sin caracterización genérica, supuso que en el momento de mayor desarrollo normativo -es en este período en el que se escriben los grandes tratados españoles del Pinciano, Carvallo y Cascales, tras el auroral esfuerzo de Herrera- se produjera su mayor negación en la práctica. La originalidad de las creaciones lopesca, cervantina y gongorina, cuajadas entre 1605 y 1613, supuso la ruptura de las normas vigentes, pero también algo mucho más profundo: la quiebra del cimiento clasicista del ars ante la originalidad individual, manifestada en forma del ingenio exaltado por Carvallo, la poética de la erudición y la agudeza conceptista ${ }^{15}$, que tiene su máxima expresión teórica, al tiempo que su práctico punto final, en la Agudeza y arte de ingenio (1648) de Gracián, que marca unos límites de la poética clasicista cuya reivindicación en la segunda mitad del XVII responde a la degradación barroquista y anticlásica producida al traspasarse dichos límites por efectos de un gusto popularizado.

Si consideramos la imitación como una de las claves esenciales de la poética clasicista, podremos ver en el camino hacia la originalidad una línea de decadencia, y en esta meta el final de la vigencia de dicha poética. El asentamiento de la emulación supuso, al tiempo que una quiebra en el valor absoluto de la autoridad, un desplazamiento del eje de la creación hacia el propio sujeto de la misma, que se desprende de los rasgos de objetivación, proporcionados por el concepto utilitario del factor referencial -la res- sancionado por la tradición que se imita. La formulación de base emulatoria de que "los tiempos modifican las artes" es la expresión del

\footnotetext{
${ }^{14}$ Evidentemente, la aparición de géneros nuevos implica también un índice de cambios históricos, estéticos y de poética, al tiempo que una modificación en el sistema canónico y, consecuentemente, en cada uno de los géneros colaterales. Ésta es otra dimensión del problema planteado, que requeriría una consideración específica, que aquí sólo podemos introducir como el apunte de una necesaria matización.

${ }^{15}$ Véase J. Roses Lozano, "El ingenio y la inspiración en la edad de Góngora", Criticón, 49 (1990) 31-49; y M. Chevalier, Quevedo y su tiempo: la agudeza verbal (Barcelona 1992), respectivamente. Es de destacar, no obstante, en este proceso la profunda transformación del concepto de "ingenio", desde el sentido platónicorenacentista de lo natural e inmanente (en oposición al ars) hasta la progresiva acentuación de la dimensión de lo individual y específico, inseparable, sin embargo, de un proceso artístico de decantación y estilización, identificado con una noción de labor artística (mímesis) que ya nada tiene que ver con la mera imitatio. Es en este sentido en el que Góngora puede considerarse como el representante más elevado de esta poética, sistetizando en su obra todos estos aspectos: ingenio, erudición, conceptismo, pero en una dimensión más profunda y compleja que la de simples modalidades estilísticas.
} 
elemento de cambio que viene a oponerse al estatismo clasicista, apoyándose progresivamente en el valor dinamizador del gusto, que antes de centrarse en el del creador, como en el artista romántico -primer anticlásico radical-, lo hará en el del receptor. Entendido en su sentido individual, como destinatario del discurso artístico, la vindicación del lugar del receptor alimentará la recuperación de la base retórica y su nueva lectura, acentuada en el período barroco en paralelo a la exaltación del ingenio frente al ars, al tiempo que el principio del deleite va ganándole terreno al de la utilidad (prodesse o docere), rompiendo el equilibrio del clasicismo horaciano. Sobre la afirmación del gusto del receptor se puede sustentar progresivamente el del creador, o, lo que es lo mismo, su ingenio o su erudición, así como la autonomía de la obra de arte, desasida ya de las exigencias de veracidad, historicidad, moralidad y, finalmente, de sometimiento a las reglas. ¿Cuáles son ahora los criterios vigentes? Hemos de acudir de nuevo al receptor, pero ahora en su dimensión colectiva, la del público, que ha ido afirmándose a lo largo del siglo XVI en todos los aspectos afectados por el desarrollo de la imprenta: sociales, económicos y culturales ${ }^{16}$. A partir de mediados del siglo XVII y en diferente medida según los discursos genéricos, el mercado, como objetivación del gusto del público, impone las normas, condicionando la creación desde el espacio de la recepción. La tensión, que será en breve la del arte moderno, se produce entre la innovación y los gustos acomodaticios, aunque persiste también entre los intentos, más o menos eruditos y elitistas, de mantenimiento y revitalización de las normas clásicas y la tendencia del público que se impone en el nuevo mercado a dejarse llevar por lo más fácil o lo más brillante. Esta dialéctica, que se acentúa hasta la mitad de la centuria, para dejar paso en ella al período barroquista, con el triunfo de los gustos popularizados, es la que inicia el período barroco, precisamente con una serie de innovaciones que pretenden dar respuesta artística a las demandas del público en sus más diversas manifestaciones socioculturales y decantaciones genéricas.

\section{3. Épica, historia y novela: límites genéricos}

En una épica en franca decadencia estos problemas y sus vías de solución estaban condenados a tener una trascendencia muy limitada, todo lo contrario de lo que ocurría en el caso de la novela, que apunta, género pujante y novedoso, una efectiva alternativa al poema heroico en la teoría, en ciertas prácticas y, sobre todo, en el gusto del público. La poética barroca pone la inventio y la elocutio al servicio de la admiratio, de la maravilla que suspende al receptor y que cumple la finalidad esencial de la retórica, el movere. El desplazamiento hacia los aspectos de la recepción que introduce el auge de la retórica no es baladí, sino que podemos apreciarlo como un modo de encauzar en moldes aún clásicos la cada vez más creciente presión del público, plasmada en el concepto de "gusto" ${ }^{17}$ que se extiende desde el Arte nuevo lopesco. Para un género culto como la épica la introducción de este elemento supone la disolución de los principios rectores de su canon, traducida en el acercamiento al incipiente

\footnotetext{
${ }^{16}$ Cfr. Elizabeth Eisenstein, La revolución de la imprenta en la edad moderna europea (Madrid 1994).

${ }_{17}$ Véase F. Sánchez Blanco, "Los comienzos de la estética del gusto en el Renacimiento español", Revista de Literatura, 102 (1989) 395-409.
} 
modelo novelesco ${ }^{18}$, hasta el punto de que la frontera entre los dos géneros va a quedar reducida a lo que en principio parece una mera cuestión prosódica. La distinción entre prosa y verso será a lo largo de la segunda mitad del XVI la marca distintiva fundamental entre el romanzo y el "romance" de aventuras, entre las persistencias épicas y el gérmen novelesco. El verso, sobre todo la octava, representará, según avanza el siglo XVII, un principio constructivo y un aval genérico, que permitirá la persistencia del poema épico, pero a costa de la pérdida progresiva de sus rasgos definitorios.

La publicación del Bernardo en 1624, aunque escrito en contemporaneidad casi estricta con la primera parte del Quijote, es un síntoma evidente de esta situación. Cuando aún los preceptistas y, especialmente, los creadores no habían acabado de sustentar la existencia de una "épica en prosa", Balbuena parece proponer con su adaptación épica de los elementos esenciales del romanzo ariostesco, a partir de su continuidad argumental, una especie de reformulación de la "épica en verso", en este caso, ceñida directamente al gusto y la demanda lectora manifestados en torno a los poemas del ciclo de Orlando y los familiares herederos del Amadís. El poema se constituye de este modo como una suerte de compromiso entre las exigencias de un público cada vez más teñido de popularismo y un género que conservaba lo esencial de su prestigio culto. De esta hibridación el autor puede obtener argumentos fantásticos, pero avalados por una auctoritas; un estilo elevado, acorde a la dignidad de sus héroes, de acuerdo con la doctrina del decoro; una vía para la amplificatio erudita y el despliegue de un valor didáctico-moral; una conexión con los géneros editoriales de mayor éxito, incluido el romancero; la mezcla de la historia con las creaciones más fabulosas de la fama y la leyenda; un efecto de maravilla a partir de elementos que ya resultan familiares para el lector; la ampliación de su público, superando los círculos más cerrados del academicismo clasicista; la posibilidad, finalmente, de unir todo ello con una función de nobilitare, culta y renacentista, pero también palaciega y barroca, que abarca por igual a la nación y al mecenas.

El desfase entre la evidencia de tales planteamientos en el desarrollo del poema y el silencio que respecto a los mismos muestra el prólogo, en el que se pretende la sujeción a unos preceptos clásicos, ilustra lo contradictorio y crítico del momento histórico que vive el género épico, sujeto aún en el terreno teórico a las normas dictadas por Tasso, en tanto que en la práctica sigue imperando, de manera más o menos directa, el modelo y el ejemplo de Ariosto ${ }^{19}$. En estos años tal situación es síntoma y efecto de la presión de la competencia que está

\footnotetext{
${ }^{18}$ Del otro lado se situaría la otra vía de la epopeya, la de una épica religiosa que no puede desligarse de la noción retórica del movere propiciada por Trento. Pero ésta es, sin duda, una dimensión singular, de incidencia sólo muy indirecta en la cuestión tratada, más allá de ser otro índice del agotamiento de la épica renacentista. Cfr. los estudios ya clásicos de G. Cirot, "Coup d'oeil sur la poésie épique du Siècle d'Or", Bulletin Hispanique, 48 (1946) 294-329; F. Pierce, La poesía épica del Siglo de Oro (Madrid 1968); y G. Caravaggi, Studi sull'epica ispanica del Rinascimento (Pisa 1974).

${ }^{19}$ Otra buena muestra de ello podría ser el caso de La Hispálica, de Belmonte Bermúdez, que permaneció inédita tras su finalización en 1618. En este poema, el marco teórico y argumental imitado de la Gerusalemme se ve atravesado de episodios y narraciones de amor y aventura con marcado sabor ariostesco. Véase la edición de P. Piñero Ramírez (Sevilla 1974). Para la influencia de Tasso, cfr. B. Cinti, "Observazioni su un rifazimiento spagnolo della Gerusalemme Liberata (Imitazione e invenzione)", Da Castillejo a Hernández. Studi di Letteratura Spagnola (Roma 1986) 121-186; A. Farinelli, "Tasso in Spagna. Una versione inedita della Gerusalemme", Italia e Spagna (Torino 1929) II, 235-286; G.M• Bertini, "Torquato Tasso e il Rinascimento spagnolo", Torquato Tasso (Milano 1957) 607-671; J. Arce, Tasso y la poesía española (Barcelona 1973); y H. Puigdoménech, "Le
} 
conociendo la épica como género avalado por la preceptiva clásica y, a la vez, de amplio predominio en el mercado editorial durante un siglo. A pesar de sus vacilaciones y de la falta de consolidación del modelo cervantino, la irrupción de la novela, con su demanda de aval teórico como "épica en prosa" y con su progresiva implantación en la producción editorial y en la lectura, supone una seria llamada de atención para los autores de poemas épicos. Mientras Lope debía recurrir aún a ellos para buscar lustre culto a su creación literaria, la consideración que sustentaba este hecho va remitiendo con el paso de las décadas entre los autores y preceptistas, pero sobre todo entre el público lector. El espacio de la épica queda ocupado al avanzar el siglo XVII por pretensiones utilitarias de literatura religiosa, completamente al margen del camino iniciado por la novela, en el que Cervantes tantea distintas fórmulas en el Quijote y el Persiles, al par que en las Ejemplares ensaya la teorización poetológica necesaria para un género exigido por una situación nueva, pero también para dar cuenta narrativa de tal situación, caracterizada por la desintegración ${ }^{20}$. El epos, último reducto de un mundo integrado, buscaba un espacio para su pervivencia, pero la historia, la presente, no ofrecía muchas oportunidades para ello, ni a los lectores, ni a los creadores, ni a los preceptistas ${ }^{21}$. La fantasía novelesca o la espiritualidad trasmundana eran prácticamente las únicas vías posibles. $\mathrm{Al}$ menos, las que transitó el género en su declive. En tal contexto, la validez de un héroe como el Gran Capitán, arrinconado por el ventero y reivindicado por el bachiller, era un índice de las posibilidades de renovación de una poética clasicista en quiebra, como pusieron de relieve los

Tasse en Espagne. Quelques considérations sur sa fortune", Revue de Littérature Comparée, LXII,4 (1988) 509520. Para Ariosto, véase el magistral estudio de M. Chevalier, L'Arioste en Espagne (1530-1650) (Bordeaux 1966).

${ }^{20}$ Véase G. Güntert, Cervantes. Novelar el mundo desintegrado (Barcelona 1993); y del mismo autor, L'epos dell'ideologia regnante e il romanzo delle passioni. Saggio sulla "Gerusalemme Liberata" (Pisa 1989), como contraste de dos universos poéticos en oposición.

${ }^{21}$ No faltaron a lo largo del siglo XVI español ejemplos de poemas épicos de tema histórico contemporáneo, hasta el punto de que, con Ercilla y Camoens, se hayan señalado como rasgos definitorios de la épica hispana. Los modelos abarcaron por igual los relatos de hechos particulares (la misma Araucana, la Breve relación de la jornada que ha hecho el señor duque de Alba desde España hasta Flandes, de Baltasar de Vargas, o La Austriada, de Rufo) y las crónicas de un reinado, concretamente el de Carlos V (Sempere, Zapata, Urrea), y significaron una inevitable aproximación entre la historia y la fabulación, entre el paradigma cronístico y los cauces de la ficción. La extensión de estos poemas comportó contaminaciones y aproximaciones en los recursos formales y un impulso a la disolución de la oposición neoaristotélica entre historia y ficción, pero no fueron éstos los únicos resultados. Incluso en un momento de exaltación nacionalista e imperialista, la cercanía histórica de los sucesos narradoscantados limita las posibilidad de la necesaria "ficción mítica" que requiere la epopeya, según A. Prieto ["Origen y transformación de la épica culta en castellano", Coherencia y relevancia textual (Madrid 1980) 117-178] y E. von Richthofen [Sincretismo literario (Madrid 1981)], en un conflicto del que ya dan cuenta las octavas de La Araucana y la polémica que suscitaron. En el otro extremo, la exaltación personalizada del héroe (Juan de Austria) o del soberano (Carlos V) se presenta como la vía más fácil para mantener la altura épica, si bien a costa de la dimensión colectiva que proporciona la glorificación del pasado nacional o la práctica del nobilitare. En conexión con este último factor, esta cercanía histórica también supone una fuerte limitación al desarrollo de la fantasía del romanzo, que requiere del mismo cronotopo mítico de la epopeya. No obstante, la presencia de este último elemento, representado por la influencia ariostesca o el modelo vernáculo de los libros de caballerías, actuará como el catalizador del género nuevo (carácter defendido para el Furioso por Cintio y negado por Tasso en su Apologia y en los Discorsi) que se desarrollará entre la épica y la historia, combinando ideas teóricas, recursos formales y criterios de veridicción de ambas, precisamente al asentar con El Quijote bases poética de la epopeya, modelos cronísticos, referentes caballerescos y el tono del romanzo en una dimensión de actualidad. Véase Ch.V. Aubrun, "Poesía épica y novela: el episodio de Glaura en La Araucana de Ercilla", Revista Iberoamericana, 21 (1956) 261-273. 
intentos de recuperación del género épico por Trillo, como modalidad panegírica o según un modelo más canónico.

A las colaterales teorías de Cervantes y Trillo ( $c f r$. nota 1) no fue ajena la común atención que uno y otro prestaron a las formulaciones de Tasso ${ }^{22}$, aunque quizá menos de manera directa que a través de fuentes interpuestas: el Pinciano y los poetas imitadores de la Gerusalemme. Las diferencias provenían del hecho de que uno optara por la vía de la prosa y otro por la del verso, con todas las diferencias que ello comportaba, y del hecho aún más trascendente de las diferentes recepciones que uno y otro obtuvieron. Si bien con un período dilatado de larvada latencia, el modelo cervantino arraigó definitivamente; la epopeya canónica, por el contrario, no superó el declive de una moda, en el que a Trillo le tocó históricamente el momento final. Sus pretensiones de clasicismo, reacción exigida por el estado de cosas de la poética contemporánea, tampoco le ayudaron en su empeño, sirviendo sólo como digno y honroso epitafio a un género moribundo y que dejaba paso en todos los terrenos a la pujante novela.

El perceptible paralelismo entre Cervantes y Trillo, invita a revisar la naturaleza genética de la novela, sus relaciones con la épica y el trasfondo de la historia. A todas luces, la corrección formulada por Senabre ${ }^{23}$ era de absoluta necesidad para replantear la tesis lukacsiana sobre la directa filiación entre la épica y la novela, vinculada a transformaciones sociales en modo mecanicista. Las observaciones sobre ciertos procesos de conformación novelística, sobre todo en el período bizantino y medieval, representan sólidas objeciones a las tesis de Lukács, pero sin agotar el problemático panorama de la conformación del género novelístico y sus raíces.

La distinción aristotélica, continuada a partir de Robortello ${ }^{24}$, de materia, instrumento y modo de imitación como criterios de distinción de las formas poéticas es el contexto en el que se sitúan las inestables relaciones entre historia, épica y novela, entendiendo por tal las diferentes formas narrativas de ficción en prosa. Lo narrativo, es decir, la forma de imitación diegética es el nexo común entre estas tres modalidades, lo que establece su familiaridad y permite la mayor parte de los trasvases entre ellas. El cambio es menor entre la crónica y la narración novelesca, pues ambas comparten también el instrumento de imitación, la prosa, frente al verso de la épica. En cambio, la materia es la que presenta una mayor fluctuación y, consiguientemente, una mayor inestabilidad. Hasta que la narración novelesca adquiere una completa autonomía para su inventio, sobre todo con la superación de las formas de narrativa idealista del renacimiento, la fábula, "alma del poema" en expresión de Trillo, procede de ese ámbito que hoy podemos caracterizar en gran medida de legendario, del que se alimenta el epos, pero que gozó durante mucho tiempo de la categoría de histórico. La única condición exigida parecía ser la de la lejanía cronológica, que era lo que oponía el relato de las guerras civiles en Roma y los orígenes de la fundación de la ciudad, consideradas ambas como verdades históricas, pero distinguiendo la consideración de la Farsalia como historia frente a la

\footnotetext{
${ }^{22}$ Véase Alban K. Forcione, "Cervantes, Tasso and the Romanzi polemic", Revue de Littérature Comparée, 44 (1970) 433-443.

${ }^{23}$ R. Senabre, "El público y la constitución del género novelesco", Literatura y público (Madrid 1986) 98-111.

${ }^{24}$ Por citar sólo tratados teóricos de incidencia en el discurso de la épica española, la idea se repite en Tasso, Pinciano y Cascales.
} 
Eneida como poesía. Para Aristóteles y sus comentaristas más sagaces la única distinción posible era la forma de contar los hechos: como realmente sucedieron o como debieran haber sucedido, pero sin que este último modo excluyera la coincidencia con la verdad histórica real. El problema de indefinición se agudiza con los trasvases de materia, que, si existían en el mundo grecolatino, se acentúan en el período medieval -con la versificación de crónicas y la prosificación de poemas épicos y romances- y encuentran una concreta manifestación en el uso por autores como Trillo de las crónicas sobre su personaje, las cuales también pueden llegar a ser aceptadas como relatos novelescos, según hiciera Juan Palomeque y aun el Cura.

La recepción resultaba, pues, determinante por la consideración de la naturaleza histórica o no de una fábula concreta y por la valoración jerárquica que se establecía a partir de ella. Para la perspectiva filosófica de Aristóteles y para la del lector Alonso Quijano la superioridad corresponde a la poesía, pues, al imitar las cosas como debieron suceder, es decir, en su perfección metafísica, está más cerca de la verdad universal que la historia, que sólo opera con verdades particulares y concretas. La inversión, que alcanza al Zoylo participante en el diálogo de $\mathrm{El} \mathrm{Cisne} \mathrm{de} \mathrm{Apolo,} \mathrm{se} \mathrm{apunta} \mathrm{en} \mathrm{el} \mathrm{siglo} \mathrm{XV} \mathrm{con} \mathrm{la} \mathrm{estrecha} \mathrm{vinculación} \mathrm{de} \mathrm{las} \mathrm{narraciones}$ en prosa de carácter novelesco a las formas cronísticas e historiográficas (la biografía en $E l$ Victorial; la relación de sucesos particulares en El paso honroso; la crónica en la Sarracina, etc.), pues éstas eran las que gozaban de máximo prestigio y cultivo por los humanistas (Hernando del Pulgar, Pérez de Guzmán y otros), lo que habría de continuarse en el XVI en la reserva del cargo de cronista para los más destacados representantes del humanismo vulgar ${ }^{25}$. La reinterpretación de los principios aristotélicos, a partir de los comentaristas italianos, propició una reactualización del concepto de mímesis, permitiendo sostener en la idea de la imitación las diferencias entre la verdad histórica y la fábula poética. Este momento, situado en las letras españolas en el paso del siglo XVI al XVII, entre Pinciano y Cervantes, es, además de la transición entre el manierismo y el barroco, el instante germinal de la novela moderna, un momento, asimismo, en el que continuaba la vigencia de algunos de los aspectos esenciales de la poética clasicista, incluida su voluntad normativa y su demanda de autoridad para las realizaciones artísticas.

Ciertamente, como género híbrido y bastardo, la narrativa de ficción en prosa, en camino a la novela, se va alimentando en su realización práctica de los modelos cercanos, entre los que la prosa cronística (biografías, relatos de viajes, crónicas de hechos particulares, etc.) tiene un papel relevante ${ }^{26}$, tanto en la formalización, como en la recepción de los textos, entre otras causas por la común vinculación a la imprenta, la extensión entre un público lector compartido por ambas, y una valoración didáctico-moral en la que progresivamente va adquiriendo relevancia el factor de deleite. Pero la constitución de la novela como género, problema

\footnotetext{
${ }^{25}$ Para escándalo de Pedro de Rúa ante la actitud de Guevara, cuya moderna conciencia de la distancia entre la verdad histórica y la libertad creativa de la poesía desconcertó los parámetros vigentes desde la centuria anterior.

${ }^{26}$ Pero también lo tiene, tanto entre los autores del XVI como entre los preceptistas aristotélicos, la tradición de la sátira menipea, generalmente asociada a los libros de caballerías en los tratados, la autoridad (reforzada por Erasmo) de Luciano, en su Historia verdadera y en sus diálogos, y su derivación y difusión en los coloquios y misceláneas renacentistas, con su componente dialogístico y hasta carnavalesco señalado por Bajtin como componente esencial de la novela. Ello sin olvidar que estos últimos elementos se encuentran ya muy desarrollados en la ironía que Ariosto desarrolla en su romanzo. Cfr. J.A. Parr, "Don Quijote". An Anatomy of Subversive Discourse (Newark 1988)
} 
planteado en el contexto cervantino del cambio de siglo, requería, sobre todo en su obligada dimensión teórica, un refuerzo más sólido, que debió buscarse en la doctrina del "poema épico en prosa", cuya recuperación entre nuestros preceptistas coincide históricamente con la evolución "novelesca" de la épica española y la influencia de Ariosto, que, tal como hicieran Bernardo Tasso, con el Amadigi, y otros autores ${ }^{27}$, funde el mundo caballeresco (en una tradición que une la epopeya medieval francesa, el roman courtois, la juglaría de los cantambachi, los libros de caballerías y los romanzi) en el molde del poema épico, si bien con las necesarias modificaciones. Así lo sostiene Tasso en sus Discorsi y en su Apologia della "Gerusalemme liberata", cuando desmiente que el Furioso represente un género nuevo, manteniendo su consideración como poema heroico, si bien imperfecto, más que la obra en prosa de Heliodoro. Y Tasso lo hace desde una consideración del modelo canónico del género en el que está operando una fusión con la historia, al menos en el plano de la inventio. Es en este marco, de progresiva aceptación de las novedades -en verso y prosa- en el paradigma del poema épico, en el que se desarrolla la novela, apoyada formalmente en los moldes menos canónicos, pero forjada teóricamente en el canon del poema épico, que es el que configura el género novelístico, con su adaptación a la prosa y, definitivamente, con su adecuación temática ${ }^{28}$, que con la forja del individuo novelesco se sitúa entre el "universal" épico y el "particular" histórico.

En tanto que se impone y se mantiene la superioridad moral de la verdad histórica, con la preponderancia de la crónica sobre la poesía, aquélla constituye sin sombra alguna el elemento de referencia, el objeto de imitación y, consiguientemente, la matriz argumental, estructural, técnica y hasta de recepción de las formas novelísticas; es lo que ocurre con los relatos bizantinos, con el roman courtois y aun con formas incipientes de la narración humanista ${ }^{29}$. Pero el panorama puede resultar distinto en períodos de vigencia de la poética aristotélica entendida en su sentido menos restrictivo. Con ella, la recuperación y vindicación de la verdad artística y de la superioridad filosófica de la poesía -tal como la ratificase Trillo- devuelve el problema de la configuración del género novelesco a las reglas del arte -tal como hiciera Cervantes-, que se condensan en los modelos canónicos de la épica. La contaminación del romanzo ariostesco y los libros de caballerías, así como el correspondiente paralelismo entre la actitudes de Tasso y Cervantes, puede ser un argumento en este sentido. La coincidencia de muchos de los planteamientos teóricos de Trillo ${ }^{30}$ con los del autor del Quijote puede insistir en ello. La reformulación de la poética clasicista en cuyos cánones genéricos diseñados para la épica pueden insertarse, casi sin desajuste, los rasgos del género novelesco definido por

${ }^{27}$ Cfr. L. Pollman, La épica en las literaturas románicas (Barcelona 1973).

${ }^{28}$ La presión de las nuevas realidades genéricas se manifiesta en el terreno teórico en la aceptación en los Discorsi del poema eroico no sólo del poema en prosa de Heliodoro, con el canon de la novela de aventuras peregrinas, sino también de la temática amorosa [cfr. T. Tasso, Prose, ed. E. Mazzali (Milano 1959) 551], que habrá de ser una de las vías más transitadas por la novela.

${ }^{29}$ Véanse, respectivamente Carlos García Gual, Los orígenes de la novela (Madrid 1972), y Primeras novelas europeas (Madrid 1974); P. Ruiz Pérez, "Caballeros y amantes. Mundos conflictivos en el roman y en la novela sentimental”, Investigación Franco-Española, 2 (1989) 109-125, y mi estudio preliminar a F. Pérez de Oliva, Historia de la invención de las Yndias. Historia de la conquista de la Nueva España (Córdoba 1993).

${ }^{30}$ Son formulados de manera expresa en el "Prólogo al lector y razón de este poema" que abre su manuscrito. Ofrezco un texto del mismo en "Una proyección de las "Soledades" en un poema inédito de Trillo y Figueroa (con edición del prólogo y libro 8 del Poema heroico del Gran Capitán)”, Criticón, 65(1995), 101-177. 
Cervantes, proporciona una matización a la génesis de la novela y una visión distinta de aparentemente elitistas y despegados intentos como los de Trillo y la poética clasicista cuya vigencia se quiere recuperar cuando el siglo XVII, como tantas otras cosas del período áureo español, se encamina hacia su ocaso. Con el peso del modelo de la Gerusalemme y de la teoría de Tasso, se sigue recurriendo a la materia histórica como refuerzo para la verosimilitud que ha de regir toda composición poética, singularmente la épica, por ser la más relevante. Aunque en progresivo declive, la idea del epos, apoyada en el pasado nacional, venía a sumarse a esta consideración, para hacer que en un momento de definitiva distinción teórica no se cortaran, sino que se mentuvieran actuantes, las relaciones entre épica e historia. Así pues, en orden a la materia, una y otra podían ponerse en la base del desarrollo de la novela, con sus semejanzas y sus diferencias.

En la constitución de la novela a partir de las formas narrativas precedentes sigue resultando operativo el modelo compositivo de la crónica, como recuerda Cide Hamete Benengeli, y con él se mantienen los debates acerca de la verdad histórica y la ficción, lo que parecía haber desaparecido por completo del ámbito de la poesía épica. De hecho, Juan Palomeque conjunta y confronta textos novelescos y cronísticos. Igualmente, el instrumento de imitación, la prosa, con su oposición funcional y genérica al verso, era también compartido por la crónica y la novela, pero quizá en este punto finalizaban sus semejanzas y sus posibles relaciones genéticas. El desarrollo de la poética, con sus vinculaciones oscilantes con la retórica, había ido desplazando su focalización hacia los aspectos de la elocutio, en detrimento de la preocupación por la inventio, sobrepasada con el debate sobre la verdad y la licitud moral de la fábula. Con ella, se producen dos fenómenos de notable importancia para la constitución del género novelesco y sus relaciones genéticas: la exclusión de la literatura histórica del ámbito de la poética y la importancia adquirida por la dispositio, como testimonia Carvallo en su tratado (parágrafo II del "Diálogo segundo"). En esta disposición tiene una cabida progresiva la variedad de las formas de imitación, que hacen que la épica junto con la novela se desplacen hacia el modo mixto, a diferencia de la crónica, que ya apenas concede espacio a los parlamentos en estilo directo. La introducción y desarrollo del diálogo en la novela tiene un correlato en la intromisión. de narradores secundarios en el poema épico, requerida por el fomento de la varietas, por el desarrollo de la estructura episódica y por el refuerzo de la verosimilitud, problemas coincidentes para ambos géneros, que con este carácter mixto se distinguen de la uniformidad diegética consolidada en los modos cronísticos. Incluso, como apunta la conexión de este último factor con el del gusto, la recepción comienza a diversificarse, especializándose y distanciándose, si no los públicos, las lecturas de una y otra modalidad, como defiende el cura cervantino en sus correcciones al ventero.

Por el contrario, donde sí se mantiene y se agudiza una confluencia de recepción, que deviene en competencia y en definitiva imposición de uno de los dos géneros, es en las relaciones -estéticas y mercantiles- de la novela con la épica. Entre ellas se había estrechado el lazo de comunidad que representaba el princio de imitatio, como clave de la poética y oposición a la historia, respecto a la que la novela sólo compartía ya el ser un relato en prosa. Aunque, como señala Aurora Egido ${ }^{31}$, para la división genérica vigente no era esencial la

\footnotetext{
31 “Las fronteras de la poesía en prosa", en Las fronteras del Barroco (Barcelona 1990) 99.
} 
distinción entre prosa y verso, la oposición sí puede ser considerada como distintiva en el caso que nos ocupa, y no tanto para establecer la contigüidad de historia y novela, cuanto para marcar las diferencias entre ésta y la épica. Ya he apuntado el carácter funcional que la oposición prosa/verso tiene en la constitución de ambos géneros, pues de ella devienen diferencias retóricas sustanciales que, si bien se concentran en el plano de la elocutio, no dejan de afectar a los restantes niveles, como cabe apreciar en la contraposición de los poemas ariostescos, aun los más "desatados", con las formas prosísticas del "romance", singularmente el caballeresco. Si la incorporación de elementos de éste a la constitución del romanzo ferrarense significó una vía de renovación de la épica culta del Renacimiento, sancionando nuevos elementos genéricos dentro del sistema poético, el proceso fue también el inverso, es decir, la novela fue alimentándose en la propuesta cervantina, como "poema épico en prosa", de los rasgos de la "épica en verso" para consolidar el nuevo género, hasta lograr el desplazamiento definitivo del verso por la prosa, apoyándose justamente en el gusto del público lector ${ }^{32}$.

Este mismo gusto, dominado por el verso en la centuria renacentista, fue el que arrastró a la versificación de la materia caballeresca de amplia circulación en prosa, pero un siglo después la tendencia del mercado lector se había invertido, y el gusto del nuevo público, menos cortesano que urbano, menos caballeresco que aburguesado, menos aristocrático y más extenso, se desplazaba hacia la prosa narrativa ${ }^{33}$. En su configuración moderna y definitiva, la novela, como relato en modo mixto de una historia en prosa apoyada en la adaptación de la poética de la épica, ocupa un espacio surgido de la intersección -de historia y poesía- de la crónica y el poema heroico, sin que ninguno pueda excluirse de una génesis tan compleja y, sobre todo, tan condicionada históricamente en sus diferentes tentativas. Monstruo centáurico, la novela en el XVII surge de este proceso de hibridación, alimentado por ese movimiento hacia la prosa narrativa, que estaba en consonancia con el proceso barroco y, especialmente, barroquista de disolución del sistema clasicista de las jerarquías estilísticas, por el que la épica en verso, precisamente por ocupar el lugar más alto de la misma, gozaba de muy superior dignidad a la del incipiente "poema épico en prosa".

Además de la tradición y el prestigio culto, sustentados en la existencia de modelos reconocidos e indiscutidos, eran las diferencias funcionales las que sustentaban la superioridad

\footnotetext{
${ }^{32}$ Es en la conciliación de ambos extremos, el de las reglas del arte y el del gusto de los receptores, donde se produce la superación de los modelos clasicistas del humanismo y el punto de ruptura que conduce al desarrollo de la novela moderna. Del otro lado quedarán los intentos de adaptación del discurso épico; $c f r$. F. Pierce, "The canto épico of the seventeenth and eighteenth centuries", Hispanic Review, 15 (1947) 1-48, y J. Cebrián, "El género épico en España: de los poemas mayores al canto épico", Philologia Hispalensis, IV,1 (1989) 171-183, síntesis del anterior.

33 Lo que aún se apunta como incipiente en la segunda mitad del XVII será lo que acabe imponiéndose en la literatura moderna, donde el mercado sustituye a la preceptiva, haciéndola cada vez más innecesaria como formulación expresa para los poetas, instaurando definitivamente lo que, a partir de Platón, venía apuntándose en el Renacimiento en torno a la égloga [ $c f r$. A. Egido, “'Sin poética hay poetas'. Sobre la teoría de la égloga en el Siglo de Oro", Criticón, 30 (1985) 43-77]. Lo que orgullosamente había afirmado Lope de Vega para el teatro tendría un correlato coetáneo en el terreno de la novela. Por contra, frente al progresivo asentamiento teórico de la lírica, la épica conocerá a lo largo del XVII una tensión entre la inercia del público y los intentos de recuperación canónica de una poética. El de Trillo puede ser el último de éstos y la constatación definitiva de su fracaso. Era el momento de la novela, aunque España hubiera de esperar más de un siglo para el inicio de su realización.
} 
de la épica sobre la novela. La selección de temas heroicos, el valor prosódico del verso culto, con los elementos de ritmo y melodía, la mayor capacidad para las figuras de dicción, la posibilidad del lenguaje sublime y el mayor espacio para la maravilla caracterizaban a un género épico superior. No obstante, la evolución del género y los cambios en la poética hicieron que estas características distintivas se perdieran al ir cediendo importancia y, sobre todo, valor jerarquizador. Era el camino abierto para la prosa, pero era también el camino para la modificación del sistema poético. Esta modificación se manifestó de manera inmediata en un reajuste del sistema genérico, menos por la aparición de nuevos géneros -como la novela-, que alteraban las relaciones entre los existentes, que por la sustitución de los criterios rectores, cada vez más alejados de los determinados por modelos de auctoritas, en favor de los condicionados por el gusto del receptor, objetivado en el mercado editorial. Cambio tan sustancial está en la base de la verdadera transformación apuntada por estos fenómenos, la de la disolución de la estética clasicista, manifestada en la reducción de su vigencia a un círculo genérico cultista y minoritario cada vez más restringido, en tanto que masivamente se imponían formas nuevas como la novela, alimentadas con la disgregación del canon genérico de la épica en verso, a pesar de los variadas tentativas para su restauración.

\section{Géneros, poéticas y cambio histórico}

El discurso de la poesía épica a lo largo del siglo XVII, hasta su práctica disolución en torno a 1650, con el significativo intento de Trillo en su Poema heroico, da cuenta de un proceso de transformación estética en el que las propias peculiaridades del género le otorgan un estatuto particular en el desarrollo de la poética que, caracterizada como barroca, se extiende a lo largo de estas décadas. Las derivaciones temáticas y estilísticas, ajenas al modelo canónico del género tal como se configura en el XVI, denotan la presión de la estética dominante, acusan un aire de época que arraiga a las obras en su tiempo. Pero, al mismo tiempo, la fuerza conformadora del género asienta el poema épico en un canon estético en el que el carácter clasicista se manifiesta con mayor firmeza que en otras manifestaciones genéricas. Las presiones existentes -de transformación y de reacción- se resuelven en tensiones que prácticamente no llegan a apagarse, lo que denota que una y otra fuerza -la de la sincronía histórica y la de la tradición genérica- se mantienen equilibradas. La aparición, el triunfo y aun la extensión de modelos que atentan contra el canon renacentista no impiden que dentro de los mismos poemas inscritos en esta línea sigan dominando los rasgos del género, al tiempo que junto a ellos permanecen con insistente pertinacia los modelos más clasicistas.

El fenómeno no es extensivo a otros géneros. La tragicomedia de Lope rompe radicalmente con las bases del teatro anterior, en tanto que su triunfo anula las manifestaciones de modelos genéricos alternativos, haciendo inviable, por ejemplo, la aparición en las tablas del corral de una tragedia clasicista. El Quijote, sin concesiones a los géneros anteriores, coincide con el final de los libros de caballerías, que no pueden volver a escribirse después, del mismo modo que la extensión de las fórmulas picaresca y cortesana en la narrativa agota la difusión de las formas derivadas de la ficción idealista del Renacimiento. Ciertamente, el barroco llega a la poesía épica, pero las manifestaciones son de distinta naturaleza en ésta que en las demás modalidades genéricas. En realidad, lo mismo ocurre con todas ellas: cada una ofrece una 
respuesta particular y propia a la coyuntura estética, es decir, la expresan con específicas diferencias formales. No obstante, cuando a lo largo del siglo XVII se debate la pervivencia de la poética clasicista ante el desarrollo del barroco, la respuesta del poema heroico, plasmada paradigmáticamente en la doble tentativa de Trillo supone una nueva llamada de atención sobre los riesgos y reduccionismos de las generalizaciones y apunta una posible clave de respuesta para la superación de estos planteamientos. En paralelo a lo que en el plano cronológico ha supuesto la disciplina de una "periodización corta" frente a las grandes construcciones sintéticas, la consideración genérica ha de actuar en el terreno de las estructuras para introducir similares deslindes, que hagan operativos los conceptos historiográficos en su acercamiento a los géneros.

Entendiendo el género como un sistema de codificación que orienta un determinado horizonte de expectativas, en esta definición se incluyen los dos elementos de fuerza que condicionan la dinámica de los géneros al compás de los cambios estéticos: la normativa conservadora y el factor de cambio que supone la demanda del consumo. Mientras, en grandes líneas, la primera se impone en la poética clasicista, marcada por la normalización y la regla, la segunda resulta preponderante en la poética moderna que sustituye a la clásica. La época barroca es precisamente la última gran etapa de la transición, y en ella, por primera vez de una manera marcada y polémica, se acentúa la distancia entre la cultura popular y la cultura elitista, cada una con sus diferentes reglas y códigos configuradores, marcos de distintos géneros. Así, la novela y la comedia lopesca se inscriben èn el ámbito de la cultura popularizada y pasan por ello rápidamente al dominio de una estética del gusto, en la que las reglas se subordinan a la demanda. Por el contrario, la cultura aristocrática, excluyente y selectiva, se apoya en el mantenimiento de las reglas, sobre las que asienta su propia identidad; y el poema épico es, ya bien entrado el siglo XVII, uno de los géneros específicos de este círculo. Ambas culturas y, consiguientemente, los géneros propios de cada una de ella conviven en el tiempo y conocen los mismos fenómenos estéticos, pero ofrecen respuestas diferenciadas.

En paralelo, la tendencia al cambio encuentra su máxima expresión en la aparición de géneros nuevos, que no siempre sustituyen por completo a los precedentes, sino que en numerosas ocasiones coexisten con ellos, si bien casi siempre separados en distintos niveles culturales. Entre estos géneros, los antiguos y los nuevos, las diferencias se radicalizan, pues a la acentuada codificación que la tradición ha impuesto a los primeros se opone la total ausencia de reglas de los que surgen sin modelos teóricos y con un proceso de adopción y desarrollo de modelo práctico frecuentemente vacilante. De nuevo, la contraposición entre el poema épico y la novela en las primeras décadas del siglo XVII es un ejemplo ilustrativo de esta situación.

Hablar, pues, de clasicismo o anticlasicismo en una época como ésta es una generalización reductora de la variedad de la estructura literaria. Hay géneros que en este momento sólo pueden establecer un discurso clásico, por tradición, nivel cultural y recepción, en tanto que otros, por los mismos factores -o por la ausencia de ellos-, están obligadamente vinculados a un discurso anticlásico. Y no basta con tomar en consideración hechos singulares como la aparición o no de este tipo de géneros novedosos, sino que la respuesta habría que buscarla en el conjunto global del sistema genérico ${ }^{34}$, por las relaciones y jerarquizaciones que en él se

\footnotetext{
${ }^{34}$ Este concepto de "sistema genérico" debe relativizarse, obviamente, cuando traspasa el empleo metodológico,
} 
establecen. El perfil del conjunto del sistema, con su jerarquía implícita, estará determinado por los ragos dominantes de una poética, pero sin que estos rasgos resulten excluyentes ni afecten por igual a todos los géneros.

El desplazamiento de un género fuera de las preferencias estéticas -teóricas o de consumode un período está vinculado casi siempre -en relación de causa o efecto o de ambas- a la rigidez de su normativa, sobrepasada por la evolución del gusto y postergada a círculos restringidos y de carácter elitista. La resistencia de estos géneros conservadores -clasicistas- se mantiene en tanto tienen un espacio de recepción, un círculo o un mercado. Por citar los dos grandes géneros codificados por la preceptiva aristotélica, la tragedia clásica desapareció rápidamente en España porque Lope se alzó con la "monarquía escénica" y su modelo resultó excluyente en tan reducido mercado, pues la realización teatral está particularmente condicionada; en cambio, el poema épico culto, asentado desde sus orígenes renacentistas en la imprenta, se mantuvo, en un circuito más amplio y menos competitivo, propiciando con esta persistencia una radicalización renovada de sus reglas, una afirmación en su modelo clasicista.

Se trata, en definitiva, del hecho elemental de que los distintos géneros presentan ritmos de desarrollo diferenciados, con la consiguiente incidencia de ello en la historia literaria, que no se mueve de modo uniforme. Las razones de la diferencia son que los géneros se ven afectados por teorías poéticas distintas, cumplen funciones dispares y poseen públicos heterogéneos entre sí, es decir, que presentan respuestas disímiles a cada uno de los factores que condicionan los cambios literarios, de modelos o de épocas, e incluso se enfrentan a problemas diferentes. El primero corresponde a la propia conceptualización del hecho literario, de la que deriva la formulación poética correspondiente. Ésta puede ser considerada de manera autónoma, en la pretensión formulada de establecer una historia y una periodización netamente literarias. Sin embargo, es difícil deslindar las cuestiones estéticas de las que constituyen el resto del pensamiento de una época o una sociedad, en el que la estética siempre aparece vinculada a las cuestiones éticas.

De la dimensión ética, primariamente destacada en la poética clasicista, surge la definición de la función de la literatura y de sus géneros, uno de los puntos de contacto más estrechos entre los hechos literarios y la sociedad. La diferencia de funciones que, antes y después de la formulación de la dicotomía horaciana, se han atribuido a la literatura esta relacionada con la propia heterogeneidad del sistema genérico. La diversidad de sus componentes depende a todas luces de los factores repetidos desde Aristóteles: el objeto imitado, el modo de imitación y el instrumento de imitación, pero ya el filósofo griego era consciente de que las diferencias sobrepasaban las dimensiones formales y de contenido, para tocar aspectos pragmáticos, como pone de manifiesto al considerar la disparidad de fines entre la tragedia y el poema épico.

Si la aparición de necesidades que demandan una función puede originar la aparición de nuevas modalidades genéricas, y sus cambios pueden afectar a los cambios de ésta, se está manifestando, sin menoscabo de ciertos elementos de autonomía, una vinculación entre la literatura y la sociedad, en la que aquélla ofrece su respuesta a través de los modelos genéricos, y ésta ofrece un primer elemento de objetivación en el público de los mismos, pues si la función del hecho literario tiene una dimensión social, el cumplimiento de sus fines se hace a 
partir de su efecto en el lector, como, más que en la Poética, subrayó Aristóteles en la Retórica, al hacer partir sus análisis y reglas de los mecanismos de recepción. Y la manera en que el público supera la abstracción y se manifiesta es a través del gusto, factor de cambio dentro de la persistencia más sostenida de la funcionalidad literaria. El gusto es cambiante con los tiempos, como reconocieron ya los preceptistas del clasicismo, pero también, en el plano sincrónico, con los diferentes niveles o círculos socioculturales, popular y elitista, que conllevan distintos géneros, adscritos a circuitos diferentes, en un precedente de lo que habrán de ser las normas del mercado, sustituto definitivo de la poética normativa en la configuración de los modelos y de los cambios literarios.

Esta heterogeneidad de los discursos literarios, progresivamente incrementada en su complejidad y, concretamente en sus diferencias genéricas, llega a superponerse al principio de unidad que comporta todo sistema y, desde luego, destierra por completo toda sombra de uniformidad. Una consideración del cambio histórico no puede dejar de tener en cuenta este factor, en detrimento de las magnas generalizaciones, en las que dicha complejidad se pierde. Aunque el sistema llega a conocer tal volumen de transformaciones que deviene en un sistema distinto, lo que varía es el conjunto de relaciones que se establecen entre sus miembros, pero ello no significa que no puedan darse pervivencias de elementos intrínsecamente inalterados de un sistema a otro, cambiando solamente su lugar en ellos. Este sería el caso de la épica: desplazada de su lugar de preeminencia jerárquica con la progresiva disolución del sistema clasicista, acentuada en la época barroca, conserva, sin embargo, hasta el final -al menos, en parte de las realizaciones del género- sus rasgos clásicos, hasta el punto de que, como ocurriera en el caso del Poema heroico del Gran Capitán de Trillo, el poeta llega a plantear, junto con la recuperación de los rasgos distintivos del modelo canónico del poema épico, los elementos esenciales de la poética clasicista, convirtiendo la reflexión y la práctica del género instaurado por Homero y Virgilio y codificado por Aristóteles en un punto de partida para la revitalización de toda una poética, de todo un sistema literario, que cada día se hacía más opuesto al contemporáneo. El que pudiera hacerlo desde este género y no desde cualquier otro de los que conservaban algún tipo de vigencia sostiene lo apuntado acerca de las diferencias genéricas y su respuestas diversas a las variaciones de las poéticas. 
